coxæ; antennæ with the first joint considerably thickened and not reaching apex of head, a little longer than breadth between eyes, which are only subprominent; third antennal joint considerably shorter than second; pronotum depressed, with an obsolete narrow anterior collar, transversely excavate on disk, lateral margins moderately sinuate and narrowed anteriorly, posterior margin molerately concavely sinuate; hemelytra with their margins parallel; membrane with a small basal ceil and three veins; anterior and posterior femora very strongly incrassated, and spinulose on their under surface ; tarsi three-jointed.

Owing to the specimen described being in a carded condition, the structure of the sternum cannot be ascertained.

Type, S. parallelus, Motsch. (Anthocoris).

\title{
Genus T'riphleps.
}

Triphleps tantilus.

Anthocoris tantilus, Motsch. Bull. Soc. Mosc. xxxvi. (3) p. 89 (1863).

Triphleps indicus, Reut. Monogr. Anthocor. pp. 91, 101 (1884).

\section{Summarized Disposition of Walker's Genera and Species} belonging to the Fumily Anthocoridæ.

Species considered valid, but requiring generic revision.

Anthocoris proximus, Walk. Cat. Het. v. p. 151 (1872), belongs to gen. Oxycarenus, Fieb. (Lygæidæ).

- pubescens, Walk. loc. cit., belongs to gen. Oxycarenus, Fieb. (Lygæidæ).

_ arctatus, Walk. loc. cit. p. 153, belongs to gen. Oxycarenus, Fieb. (Lygæidæ).

Xylocoris fulvescens and fumipennis, Walk. loc. cit. p. 160, belongs to gen. Amphiareus, nov.

Species treated as synonymic.

Anthocoris subcruciatus, Walk. Cat. Het. v. p. 151 (1872),= Oxycarenus maculatus, Stål (Lygæidæ).

Xylocoris fumipennis, Walk. loc. cit. p. 160,=Amphiareus fulvescens, Walk. loc. cit.

XXXIV.-On new Species of Rhopalocera from Sierra Leone. By George T. Bethune-Baker, F.L.S., F.Z.S.

LAST year Mr. Cator added considerably to his collection of Rhopalocera in the near hinterland of Sierra Leone, both in species and in numbers, and he brought home or sent over to 
me many very interesting species, among others that most interesting and rare Argyrocheila undifera, Stgr., which, owing to the keenness of observation and enthusiasm of Mrs. Cator (who spent a couple of months with her husband), they were able to take in some numbers. Mr. Cator reports it as one of the most shy species he knows; it is not a strong flier, as we might imagine, but at the very least alarm it drops instantly, and it is almost impossible to find it in the undergrowth, so that, with its uncertain flight, it is by no means easy of capture. There are several new species in the collection which I here describe; my measurement for the expanse of wings is taken by doubling the distance from the centre of the thorax to the apex of the wing. The types are in Mr. Cator's collection.

\section{Acrcea Catori, sp. n.}

๙. Primaries diaphanous, with the apical area blackish grey for two fifths between the apex and the end of the cell; termen broadly dusky, slightly tapering to the tornus; a broad, dusky, diagonal band from the costal margin of the cell across the angle of vein 2 to near the tornus; a twin dusky spot at the end of the cell, followed by a large twin spot just beyond it ; the space between veins 3 and 4 dusky; costa slightly dusky to the cell. Secondaries dull strawcolour, with a very broad dark termen, with the veins and a central stripe in the vein-spaces darker and extending well beyond the dark terminal area, several small black spots at the base. Under surface: primaries with all the pattern showing through, but the apical area and termen tinged with ochreous; the veins and a slight central dash in the veinspaces dusky. Secondaries brownish ochreous, with two black spots at the base over the cell, two spots near the base in the cell, and two smaller spots on the discocellulars; two spots just outside below the cell at the base, followed by two below them; an oblique row of three spots, the upper one in the angle of vein 2. All the veins are dusky for nearly their whole length, and there is a long, central, dusky stripe between each.

. Like the male, both above and below, but larger and the secondaries are rather paler.

Expanse, ơ 72-73, ๆ $83 \mathrm{~mm}$.

This species will come between A. epidica, Obth., and vesperalis, Smith.

Euptera Dorothea, sp. n.

3. Head, thorax, and abdomen extremely dark olive-green, 
greyish below; thorax with patagia tipped with creamy yellow, with two anterior spots and two lunular posterior marks of the same colour; abdomen banded above with the same colour. Both wings extremely dark olive-green, so as to look almost blackish with the naked eye, with very pale creamy yellowish markings. In the primaries there is a short dash on the upper margin of the cell at the base, followed by two spots and the outline of a spot at the end of the cell; below these there is an oblique somewhat irregular dash, followed by a broad oblique band ending in a spot above vein 3 , the veins show blackish through; above this band are three dashes shaped thus _- ; a subterminal irregular row of spear-shaped markings, followed by a trace of a very fine line. Secondaries with a subbasal and postmedial broad transverse band, a subterminal row of spear-shaped marks followed by a distinct fine line.

Under surface of both wings ochreous grey. Primaries with a white basal dash on the upper margin of the cell, followed by an ochreous-brown spot encircled with black, and again with white, below which is a small black spot; at the end of the cell is an irregular mark almost encircled with white, a broad whitish oblique band of three large spots, with three whitish dashes, following the upperside markings; beyond, below vein 2 , is a black patch with a series of dark points to near the costa, followed by the subterminal white spear-shaped marks and a fine whitish line as on the upper surface. Secondaries with a basal, medial, and postmedial whitish band, the latter spotted and extending to vein 7 ; beyond this latter is a series of small, distinct, black spots right across the wing, followed by the subterminal whitish spear-shaped marks and fine whitish line.

+ . Both wings brown, with similar markings to the male, but white, with the addition in both wings of a row of large dark spots before the spear-shaped marks. The under surface is yellower than in the male, with all the markings intensified.

Expanse, ชั 54, 59-60 $\mathrm{mm}$.

This insect is probably the West Coast form of elabontas, Hew., but it may be recognized by the much broader and larger postmedial band of the primaries, and by the mark in the cell being quite linear ; in Hewitson's insect there is a largish cell-spot, above which is a second small one; the two bands in the secondaries are much wider than in elabontas and not spotted, and the under surface is uniformly pale.

\section{Pseuderesia moyambina, sp. n.}

๙. Both wings brown, primaries with a large postmedial 
orange-red patch in the anal angle, fringes tessellated white and brown.

Underside.-Primaries: basal two thirds brownish grey, outer third orange-red, fading into yellowish at the apex and termen and into pale ochreous at the tornus; the costa is grey, irrorated darkly ; a broad oblique dark dash is beyond the cell in the orange area, followed by a dark, finer, curved line below the apex; termen black, interrupted in the veinspaces. Secondaries pale grey, almost entirely covered with diluted vermilion-red, the only grey spaces being helow the outer half of the cell, the costa, and the terminal area; a black dot beyond the middle of the costa and a black point at the base below the cell, a large black spot palely encircled above and below the cell and a slightly larger one closing the cell; a postmedial very irregular vermilion-red band finely edged on each side with black, beyond which the terminal grey area is irrorated with black.

Expanse $34 \mathrm{~mm}$.

The species will follow P. libentina, Hew., but the upperside will at once separate it from Hewitson's species, and on the under surface the apical area of the primaries is different.

\section{Pseuderesia Catori, sp. n.}

๙。. Both wings brownish black, with black fringes slightly interrupted with whitish. Secondaries with a large deep yellow patch below the cell extending to the inner margin into the anal angle. Underside of both wings blackish grey. Primaries with a subapical red-spotted band of five spots, the first and the last being the smallest. Secondaries with the basal area more or less covered with red patches, with three black spots placed in a triangle above and below and closing the cell, that closing the cell being the largest; a submarginal, very irregular, interrupted red stripe edged laterally with black, the internal edging being heavy.

Expanse $33 \mathrm{~mm}$.

Two specimens of this insect were taken by Mr. Cator at Moyamba; it will come next to $P$. debora, but the patch on the upperside of the secondaries will distinguish it, whilst on the under surface it has much more pattern generally and very much more red in the basal area.

\section{Liptena diversa, sp. n.}

$\delta$. Both wings blackish grey, with a single black spot in each wing at the upper angle of each cell; in the secondaries the costa is narrowly whitish. Underside: both wings whitish, with the cell-spots just mentioned prominently 
blackish. The primaries are finely irrorated with brown over the costal half of the wing, very densely in the apical area ; a subterminal, narrow, marginal scalloped line, followed by a paler one; termen brown, interrupted finely on the veins: secondaries finely irrorated all over with brown, rather more densely in the apical area; termen finely white, preceded by a brown scalloped line finely interrupted at the veins; below the cell there is a small dark spot.

Expanse, бo, 27-34 mm.

This species is nearly allied to ilma, Hew., but it is much larger, the underside is quite different, the brown irrorations present a marked distinction, and it has none of the very definite dark pattern as in Hewitson's species. My insect flies, moreover, in December, whilst ilma flies in April and June. It would be interesting to discover by breeding whether or not this may be the early brood to ilma.

\section{Micropentila mabangi, sp. n.}

๙. Head, thorax, and upper part of abdomen blackish, abdomen below pale brown; palpi blackish above, creamcoloured below and laterally; legs black, ringed with creamcolour. Primaries blackish brown, with a postmedial, obscure, angled, yellowish stripe : secondaries blackish brown, with a broad, medial, transverse, orange band from the inner margin to below vein 7 . Underside : both wings blackish grey, with yellowish stripes and spots: primaries with three cell-spots, the first two almost linear, the third at the end of the cell larger, distinct, and cream-coloured; inner margin cream-coloured, from which a pale orangeyellow, curved, postmedial stripe ascends to the costa, tapering as it ascends and broken at vein 6 ; a trace of a very fine interrupted spotted submarginal line followed by another distinct line, with a blotch between veins 5 and 6 uniting the two. Secondaries with two basal spots, followed by a series of three, which is again succeeded by two or three spots, that on the costa much larger than the others; up to this spot the costa is broadly scaled with ochre scales; a broad, irregular, postmedial band from the inner margin to the costa, beyond which is a fine line interrupted at the veins, with another very irregular subrnarginal stripe followed by a fine line of the ground-colour; termen itself finely ochreous.

Expanse $28 \mathrm{~mm}$.

This species is somewhat near $M$. Alberta, Stgr., but is evidently distinct. 


\section{Epitolina Catori, sp. n.}

5. Thorax, abdomen, and both wings dark steely blue, with a slight purplish tint. Fringes intersected white and blackish. Underside darkish neutral grey with red markings : primaries with three red transverse dashes in the cell, above the cell thickly irrorated with red, two red costal spots followed by a short red irregular stripe, another small red costal spot, and a terminal double red line enclosing the ground-colour, and so making a row of spots edged with red: secondaries with three basal spotis and red irrorations above, followed by two more spots in the cell, with one above and below, that below being a double spot; a postmedial red spotted stripe, with a space between the two costal spots and those below vein 6 ; a very distinct double, red, terminal line enclosing spots of the ground-colour-this character is most conspicuous in the secondaries.

q. Both wings brown: primaries with a very broad orange patch, tapering rapidly towards the costa, but not extending up to the costa: underside like the male, but the primaries have the orange patch showing through and extending right across the wing, the grey of the ground-colour is paler, and most of the spots are redder and are rather more accentuated, but the pattern is less distinct.

Expanse, of 31, o $29 \mathrm{~mm}$.

Several specimens were sent home by $\mathrm{Mr}$ Cator, and it is a well-marked species.

\section{Phytala leonina.}

This species was described by me in this Magazine last year at page 328 (vol. xii.), and I placed it in the genus Phytala; but Mr. Cator subsequently brought home more material, enabling me to denude the underside of the scales, and this shows that veins 11 and 12 of the primaries do not actually anastomose, but merely touch each other; the species should therefore be transferred to the genus Epitola. Staudinger, however, has already described an Epitola leonina, so that my species will require a new name. I therefore propose to call it Epitola leonensis.

\section{Epitola Dorothea.}

d. Palpi cream-coloured at base and at the base of the second segment, which is ovate in shape; terminal segment and upper part of second segment brown.

Both wings bright blue. Primaries with the costa to 
vein 12 black; a large wedge-shaped black patch closing the cell; vein 1 is slightly swollen for over a third, and for all its length it is devoid of blue scales, especially in the basal and tornal areas, making it stand out prominently ; the blue area terminates near the posterior margin very irregularly; the black termen and broad black apex invade the blue on the veins, giving it a strongly dentate margin ; fringes finely whitish : secondaries with the costa blackish to vein 6 , but with a sparse scattering of fine blue scales above that vein in the apical area ; termen narrowly black, the blue area having a definite termination. Under surface: both wings brownish grey, with numerous whitish markings. Primaries with two interrupted lines across the cell and another long and broader one beyond the cell; a postmedial dentate line, a double submarginal line, the inner of the two being scalloped; area below vein 2 white. Secondaries with a slight pale patch at the base, a twin patch across the cell; a small spot above and below the cell nearer the base; a trace of a very interrupted line at the end of the cell, followed by a short interrupted line beyond the end of the cell; a postmedial interrupted curved line all across the wing; a double subterminal line, the inner one strongly scalloped, the outer one less strongly so.

o. Primaries blackish, with a large white patch over the centre of the wings, tapering rapidly above vein 3 , this patch extends from vein 1 to vein 11 ; the cell and the area between the lower margin and vein 1 are covered sparingly with very fine pale blue scales: secondaries uniform dark brownish grey, with a trace of a few blue scales at the end of the cell. Under surface : primaries with the white patch as on the upperside, only extending to the inner margin, and becoming cream-coloured above vein 4, with the double terminal line as in the male: secondaries as in the male, but with fewer markings.

Expanse, ơ 44, o $42 \mathrm{~mm}$.

This species is near cercene, Hew., but the black patch at the end of the cell and the black and swollen vein 1 will separate it on the upper surface, whilst below my species has many more markings and more white, especially below vein 2 .

\section{Epitola sublustris, sp. n.}

๙. Primaries dark brown, with a large patch of finer scales of a very deep dark bluish colour occupying about the basal two thirds; this patch has a peculiar lustre, having the tone of dark indigo gone greasy: secondaries bright darkish 
blue, with a broad blackish-brown border all round; veins $2,3,4$ stand out black in the blue area, vein 4 being prominently so to the base. Under surface: both wings greyish brown : primaries with a whitish inner margin, above which is a blackish area to vein 5, with two small whitish spots near its upper outer extremity : secondaries uniform greyish madder-brown, with a distinct trace of a postmedial spotted band, the obscure spots being of the same colour as the ground-colour, but placed in a band slightly paler in colour.

q. Both wings uniform darkish brown, primaries slightly darker in the cellular area. Underside like the male, but browner; in the primaries the black area is intensified and the two spots more defined.

Expanse, ơ 34, o $36 \mathrm{~mm}$.

This species is like none that I know of; the peculiar colour of the primaries contrasted with the lustrous colour of the secondaries should render it recognizable at a glance.

\section{Epitola kholifa, sp. n.}

o. Primaries with the costa blackish to the cell, the apical area and termen very broadly blackish, the latter tapering very rapidly below vein 3 ; the bright blue area is thus restricted in an even curve to the inner marginal three fifths of the wing, being margined by the upper border of the cell, at the end of which is a small black wedge, beyond which the blue extends, tapering off from there to the tornus, the margin being invaded with black at the veins; the lower margin of the cell is much swollen, the vein being covered with brownish scales, thus forming a conspicuous patch, almost reminding one of a Satyrid : secondaries bright blue to well beyond vein 6 , with a fine brown termen. The under surface of both wings is greyish madder-brown, fading into greyish towards the termen, with a few irregular, obscure, indefinite markings in the basal and median areas: in the primaries there is a broad, obscure, straight, subterminal, indefinite greyish line; in the secondaries there is a trace of a postmedial grey line, followed by a double subterminal one, the outer of which is fine.

. Primaries blackish brown, with a pale blue area as in the male, but more restricted, not filling the cell nor extending nearly to the tornus; beyond the cell are four whitish spots, the second and the fourth from the costa being the largest: in the secondaries the blue area extends only to vein 6 and there is a very broad dark termen. On the under surface both wings are pale greyish brown, with scarcely a trace of Ann. \& Mag. N. Hist. Ser. 7. Vol. xiv. 16 
any markings, except that in the primaries the whitish spots beyond the cell show through slightly.

Expanse, of $39-44$, \& $44 \mathrm{~mm}$.

This species will come next to leonina, Stgr., but may be known at once by the male sex-mark, viz. the swollen vein; the blue colour is decidedly brighter, and below there are less markings than in Staudinger's species; the fine postmedial transverse line of the primaries is quite wanting in my insect.

The specimen I have described as the female was observed by $\mathrm{Mr}$. Cator to be flying with the male, the two insects toying together, and he caught them at once with one sweep of the net, though they were not actually "in copula."

\section{Epitola albomaculata.}

Mr. Cator has brought home a series of this species, including several females, and as this sex has not been described, it will be well to do so now.

o. Both wings azure-blue: primaries with costa blackish brown to the cell, beyond which the dark area increases considerably; apical area for a third of the wing blackish brown, in which (area) well beyond the cell there is a white ovate spot between veins 4 and 5 ; termen broadly blackish brown, increasing suddenly above vein 3 : secondaries with costa brown to cell and up to vein 6 ; termen very broadly brown. Under surface precisely like the male, but with the whitish markings slightly accentuated.

\section{Epitola virginea, sp. $\mathrm{n}$.}

. Primaries dark brown, with pale azure-blue scales in the cell, at the end of which and beyond is a whitish spot with a few superimposed blue scales; well beyond this is another whitish spot; the inner marginal area is covered for two thirds of its length with similar pale azure scales extending up to the cell and to vein 2, ending in a goodsized whitish spot with a few superimposed blue scales; above it is another smaller white spot: secondaries with the pale azure area confined between veins $1 b$ and 6 , and with a very broad brown termen. Under surface: both wings whitish, with brownish-grey marks. Primaries with three irregular spots in the cell with white centres; an extremely serrated and irregular postmedial line, with the serration on vein 4 extended into the submarginal line, and that on vein 2 extended finely along the vein to the termen; the area before this line is whitish, whilst the area on the outside is pure 
white ; an interrupted subterminal line, followed by a double scalloped line; inner marginal area below the cell brownish, followed by a whitish spot, which is bordered by a brownish lunule, beyond which the wing is white to the tornus. Secondaries with three basal spots across the cell and three spots in the middle of the cell; in each case the central spot is in the cell, and there is one above and one below it; a long narrow spot closes the cell, which forms the middle of an irregular line; just beyond this is an irregular postmedial dentate line, followed by a broad whitish irregular band, edged by a subterminal dentate line, beyond which is a row of lunular spots ; the termen is finely brownish, preceded by a fine whitish line, which is edged internally by a fine brownish line. Fringes of both wings whitish, finely intersected at the veins.

Expanse 40-41 mm.

The male of this species has yet to be discovered. It is nearest to albomaculata, mihi, but is certainly distinct from that; the upperside is quite different, whilst on the under surface the spots are decidedly smaller and broken so as not to form striæ, whilst the strongly serrated postmedial lines form a very marked distinction from albomaculata.

\section{Deudorix leonina, sp. $\mathrm{n}$.}

o. Primaries blackish, with a large, dark, bright blue patch occupying the basal two fifths of the wings; at the end of the cell is a very large round spot, which extends into the black termen; all the veius stand out black; fringes black: secondaries blackish, the lower half of the cell and the area between veins 1 and 5 blue, with the veins black; on the termen above vein 5 is a small patch of blue scales; termen black, with white fringes; lobe orange-yellow; tail long, black, tipped with white. Under surface similar to otrceda, Hew., except that in the primaries there is an indefinite white subterminal stripe between the orange-brown stripe and the termen.

Expanse 30-34 mm.

This species will come next to otrada, Hew., but it may be recognized at once by the black spot of the primaries invading the black termen; in Hewitson's insect this spot is isolated in the midst of the blue area: leonina also has a very broad, dark termen, and all the veins stand out black; in otroeda this is not the case.

It is probable that this species may stand in collections mixed up with otrceda, but there is no doubt that they are two species; both fly in January and also in March. 
I have carefully examined the types of both Hewitson's species, otrceda and genuba, and find that Aurivillius was correct in sinking the latter name as a synonym; they are certainly the same insect.

\section{Hypolyccena moyambina, sp. $\mathrm{n}$.}

๘. Both wings black; secondaries with a trace of a fine short dash of blue scales in the fold and also in the lobe. Fringes of primaries black, of secondaries white below the apex. Thorax and abdomen with a trace of a few blue scales here and there. Underside of both wings whitish: primaries greyish in the apical and terminal areas; a reddishbrown sex-patch below the cell, an orange-red postmedial stripe edged with brown, a subterminal fine interrupted line edged outwardly with whitish from well below the costa; cell closed with a white dash finely edged with a darkish line. Secondaries with the closing of the cell so fine as to be scarcely discernible; the postmedial stripe broadly orangered and darkly edged unwaved to vein 1 , where there is the $\mathbf{W}$-shaped indentation up to the inner margin; a fine dark scalloped subterminal line, outside which is a row of greyish spots ; termen black, linear; a velvety-black lobe-spot finely encircled with blue, with a small bright red spot above; between the tail and the outer very short tail, both of which are tipped and fringed with white, is a large black spot edged with orange-red, a distinct whitish space between it and the lobe-spot.

Expanse $28 \mathrm{~mm}$.

$\mathrm{Mr}$. Cator took but one of this very pretty little species, but it is quite distinct from any other of the genus that I know.

\section{Iolaus Catori, sp. n.}

б. Primaries deep lustrous blue, with a slight irroration of paler blue scales in parts near the base and in the cell; costa broadly black; apex black to upper angle of the cell; termen broadly black, rapidly tapering to vein 2 , below which to tornus it is linear; a pencil of bluish-black hairs on the inner margin. Secondaries bright darkish lustrous blue, with a large darker central patch in certain lights ; the large shining patch extends to the lower margin of the cell, and on the upper margin to the costa is a large patch of differently placed scales, purplish and greenish, with a fine iris of bronzy-green scales; the whole patch appears different colours in different lights; below it, 


\section{$2 \mathrm{BHL}$ Biodiversity Heritage Library}

Bethune-Baker, George Thomas. 1904. "XXXIV.—On new Species of Rhopalocera from Sierra Leone." The Annals and magazine of natural history; zoology, botany, and geology 14(83), 222-233.

https://doi.org/10.1080/03745480409442999.

View This Item Online: $\underline{\text { https://www.biodiversitylibrary.org/item/88431 }}$

DOI: https://doi.org/10.1080/03745480409442999

Permalink: https://www.biodiversitylibrary.org/partpdf/243778

\section{Holding Institution}

Smithsonian Libraries

\section{Sponsored by}

Smithsonian

\section{Copyright \& Reuse}

Copyright Status: Public domain. The BHL considers that this work is no longer under copyright protection.

This document was created from content at the Biodiversity Heritage Library, the world's largest open access digital library for biodiversity literature and archives. Visit BHL at https://www.biodiversitylibrary.org. 